\title{
INDIAN RURAL BANKING - ROLE OF REGIONAL RURAL BANKS
}

\author{
Mr Bhavik Barot, Dr Gurudutta Japee
}

\author{
Research Scholar, \\ SD School of Commerce, \\ Gujarat University, Ahmedabad \\ Associate Professor, \\ SD School of Commerce, \\ Gujarat University, Ahmedabad
}

\begin{abstract}
The financial possibility of the RRBs (Regional Rural Banks) has, however, been a matter of concern since the 1980s, just five years after their existence. A number of committees have gone into the issue of their financial possibility and feasible restructuring. India's economy is primarily rural in nature. Over the past few years rural India has witnessed an increase in the buying power of consumers, accompanied by their desire to upgrade their standard of living. In order to shape the present rural scenario there is an urgent need of upgrading various factors like employability, literacy, irrigation, infrastructure, advanced technologies, basic telecommunication facilities and above all need of efficient financial system. This study made an attempt to enquire as to factors that influence the performance of the RRBs and the role-played by these banks.
\end{abstract}

Keywords: Entrepreneurs; production; development; employment; agriculture and indebtedness.

\section{INTRODUCTION}

Rural growth is not merely growth of rural areas but also the development of the rural people into selfsufficient and self-financing modern little communities. Rural development in the nation is designed to enhance the socio-economic living conditions for the people living in rural India while conserving their culture and rich tradition. The Government seeks to achieve higher targets related to rural production, employment and higher living standards which will pave the way for all round economic development of the country. This includes setting up basic infrastructure and facilities such as medical facilities, schools, and transport facilities, apart from scheme implementation related to improving rural employment, agricultural productivity and rural industrialization. The rural population in India suffers from a great deal of indebtedness and is subject to exploitation in the credit market due to high interest rates and the lack of convenient access to credit. Rural households need credit for investing in agriculture and smoothening out seasonal fluctuations in earnings. Since cash flows and savings in rural areas for the majority of households are small, rural households typically tend to rely on credit for other consumption needs like education, food, housing, household functions, etc. Rural households need access to financial institutions that can provide them with credit at lower rates and at reasonable terms than the traditional money-lender and thereby help them avoid debt-traps that are common in rural India. The Regional Rural Banks have been growing in importance since their inception in 1975 as special institutions playing a catalyst role in the development of rural areas. They have been playing a significant role in financing the weaker sections of the community in the rural areas and also in inculcating banking habit among rural masses. Regional Rural Banks were set up with a view to developing the rural economy by providing credit and other facilities, particularly to the small and marginal farmers, agricultural laborers, artisans and small entrepreneurs. Being local level institutions, RRBs together with commercial and cooperative banks, were assigned a critical role to play in the delivery of agriculture and rural credit.

\section{LITERATURE REVIEW}

Patel and Shete (1980) made a valuable study of performance and prospects of RRBs. They also gave a comparative picture of performance in deposits, branch extension and creditoperation of the cooperative banks, commercial banks and RRBs in a specified area. This was an eye opener for many researcher engaged in this field of rural credit.

Financial Express, (1986) published a study on RRBs viability, which was conducted by Agriculture Finance Corporation in 1986 on behalf of NABARD. The study revealed that viability of RRBs was essentially dependent upon the fund management strategy, margin between resources mobility and their deployment and on the control exercised on current and future costs with advances. The proportion of the establishment costs to total 


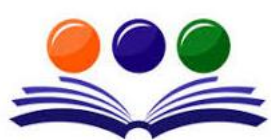

GRAND ACADEMIC PORTAL RESEARCH JOURNALS

A GLOBAL JOURNAL OF SOCIAL SCIENCES

( ISSN - 2581-5830)

Impact Factor - SJIF - 4.998, IIFS - 4.375

Globally peer-reviewed and open access journal.

cost and expansion of branches were the critical factors, which affected their viability. The study further concluded that RRBs incurred losses due to defects in their systems and as such, there was need to rectify these and make them viable. The main suggestions of the study included improvement in infrastructure facilities and opening of branches by commercial banks in such areas where RRBs were already in operation. However the main limitation of the study was that its generalizations were based on the study of only two RRBs, namely, the Mala Prosha Gramin Dharwar (Karnatka) and The Royal Seems Gramin Bank (Andhra Pradesh).

Naidu, L. K. (1988) conducted a study on RRBs taking a sample of 48 beneficiaries of rural artisans in Cuddapah district of Andhra Pradesh under Rayale Seen Gamin Bank. In this study, it was concluded that the beneficiaries were able to find an increase in their income because of the finance provided by the bank.

Kalkundrickars (1990) in his study on Performance and Growth of Regional Rural Banks in Karnataka cocluded that these banks had benefited the beneficiaries in raising their income, output, employment and use of modern practices and re-establish the rural artisans.

Kumar Raj (1993) carried out a study on the topic "Growth and Performance of RRBs in Haryana." On the basis of the study of all RRB of Haryana, it is found that there was an vast increase in deposits and outstanding advances. The researcher felt the need to increase the share capital and to ensure efficient use of distribution channels of finance to beneficiaries.

Dilip Khankhoje and Milind Sathye (2008) have analyzed to measure the variation in the performance in terms of productive efficiency of RRBs in India and to assess if the efficiency of these institutions has increased postrestructuring in 1993-94.

\section{STRUCTURE AND FUNCTIONS OF THE REGIONAL RURAL BANKS}

The Regional Rural Banks (RRBs) aimed at providing credit and other facilities to the small and marginal farmers, agricultural laborers, artisans an small entrepreneurs in rural areas. The RRB Act, 1986, empowers the Central Government to establish in a State or Union Territory one or more RRBs when any sponsor bank makes such a request. The sponsor bank assists the RRBs in many ways by subscribing to its share capital, by helping in its establishment, by assisting in recruitment and training of its cadre, and in general providing such managerial and financial assistance sought by the RRBs. The RRBs functions within the local limits as specified by government notification. It can have its branches at any place as notified by the government.

\section{ORGANIZATION STRUCTURE OF THE RRBS}

The authorized capital of an RRB is fixed at Rs. 1 crore and its issued capital at Rs. 2 lakhs. Of the issued capital, 50 per cent is to be subscribed by the Central Government, 15 per cent by the concerned State Government and the rest 35 per cent by the sponsoring bank. The working and affairs of the RRBs are directed and managed by a Board of Directors consists of a Chairman, three directors to be nominated by the Central Government, and not more than two directors to be nominated by the State Government concerned, and not more than 3 directors to be nominated by the sponsoring bank. The chairman is appointed by the Central Government and his term of office does not exceed five years.

\section{FUNCTIONS OF THE RRBS}

The functions of the RRBs are as follows: Granting of loans and advances to small and marginal farmers and agricultural laborers, whether individually or in groups, and to co-operative societies, agricultural processing societies, cooperative farming societies, primarily for agricultural purposes or for agricultural operations and other related purposes; Granting of loans and advances to artisans, small entrepreneurs and persons of small means engaged in trade, commerce and industry or other productive activities within its area of cooperation.

\section{THE FIRST FIVE RRBS IN INDIA}

Name of RRBs Sponsoring States Banks Districts covered as:

I. Prathama Bank Syndicate Bank U.P Moradabad

II. Gorakhpur kshetriya State Bank of India U.P Gorakhpur and Gramin Bank Deora

III. Haryana Krishi Punjab National Haryana Bhiwani Gramin Bank Bank

IV. Gour Gramin Bank United Bank West Bengal Malda, Dinajpur of India and Murshidabad

V. Jaipur-Nagpur United Commercial Rajasthan Jaipur and Nagpur Anchalik Gramin Bank

(Source: Rais Ahmad "Rural Banking and Economic Development"

(1998). Mittal Publication, New Delhi. pp-10) 


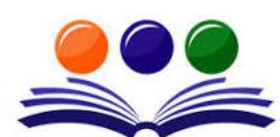

GRAND ACADEMIC PORTAL RESEARCH JOURNALS

A GLOBAL JOURNAL OF SOCIAL SCIENCES

( ISSN - 2581-5830)

Impact Factor - SJIF - 4.998, IIFS - 4.375

Globally peer-reviewed and open access journal.

\section{OBJECTIVES AND METHODOLOGY}

Objectives of the Study: The main objective of the study is to evaluate the growth of Regional Rural

Banks of India. The specific objectives are given as:

? To assess the growth pattern of RRBs;

? To evaluate the importance of geographical distribution of RRBs; and

? To recommend some workable suggestion to

Research Methodology: In order to achieve the research objectives the blend of deductive and inductive research approach is selected, whereas qualitative research method is utilized. The research is based on only publically available information which has been taken into account. In order to fulfill proposed objectives data on various facts related to the RRBs and Rural India is been presented with the help of literature review. The data is collected using secondary method to fulfill different issues related to research topic from the published articles, journals, reports, websites, blogs and academic literatures

\section{RESULTS AND DISCUSSION}

Progress of RRBs-Current Scenario: The progress of RRB in the initial stages was quite rapid. At present 196 RRB in 23 states with 14500 branches operating in the country. The total deposit with RRB in 2004-05 amounted to Rs. 58350 crores and their advances came to Rs. 31770 crores. Over $95 \%$ of the advances of the RRB are direct advances to small marginal farmers, landless laborers and rural artisian or, in other words to weaker section of the society. More especially about 48\% of RRB loan assistance is to agricultural and 52\% for non-agriculture (rural artisian, retail trade, etc). State wise, the largest number of offices in a single State is to be found in Uttar Pradesh (3100) followed by Bihar (1950) and Madhya Pradesh (1620). RRB has an important role to play in our rural economy, as they have to act as alternative agencies to provide institutional credit in rural areas. In course of time it is necessary to remember that they have not been set up to replace cooperative credit societies but act as a supplement to them. RRB has always been active participant in programmes designed to provide credit assistance to weaker sections.

Step for improvement: The Regional rural Banks in order to provide regularized services and to ensure the development of the rural India must take the following steps:

- These banks must try to reach out to the needy through micro-credit and Self-Help Groups.

- It shall provide easy and affordable services through the best use of technology.

- Expand its reach in the rural areas through alternate channels.

- Attention should be given to the financial inclusion of unbanked rural area.

- Improvement in service levels in rural areas.

\section{CONCLUSION}

Depending on the context and applications, the term performance may have different connotations. Keeping in consideration the varied activities being performed by rural regional banks, any appraisal of their performance may become meaningful with its underlying objectives. In the present study, for the performance of Regional Rural Banks an attempt has been made in terms of certain defined,

parameters, like growth pattern of RRBs; the credit distribution of RRBs; and the geographical distribution of RRBs. Till the birth of RRBs in India, branches of commercial banks and co-operative banks in thousand numbers were operating in the rural areas. But despite of such large network of bank branches, the credit needs of rural India was quite inadequate. As a constituent extensive of commercial banking network, the RRBs have achieved tremendous growth in term of number of bank and its branches. It has extended its service to every nook and corner of the country covering 487 districts in 26 states. Out of the 26 states, Uttar Pradesh has the highest number of 36 RRBs followed by Madhya Pradesh with 19, and Bihar with 16 RRBs, and these three states constitute 36 percent of the total RRBs in India However, the distribution of bank is not same in different states. The highest bank number of are in Uttar Pradesh with 36 banks and the RRBs are yet to its activities in Delhi, Goa, Sikkim and all Union Territories. Moreover, the overall position of RRBs in India is not quite encouraging. The poor credit-deposit ratio is still making big dent on the desired functioning of RRBs. Since the RRB is a bank for poor people, it's presence in all the states of country especially in underdeveloped states and Union Territories is strongly realized. The government should spread the branches of RRBs to grass root level to provide banking and credit service to the needy people in rural India. Moreover, it is the responsibility of the bank management and the sponsored bank to take the change for corrective majors to raise the credit-deposit ratio of the bank. The gap between C-D ratio of commercial banks and RRBs need to be minimized and with the result the rural India tends to gain benefit of credit policy in the rural. 


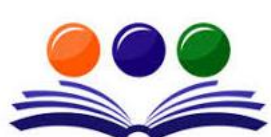

GRAND ACADEMIC PORTAL RESEARCH JOURNALS

\section{REFERENCES}

[1] Bernanke, Benjamin and Mark Gertler (1989) Agency Costs, Net Worth, and Business Fluctuations,

[2] American Economic Review, 79(1), 14-31.

[3] Jasvir S. Sura (2006) Regional rural banking in context of India, The Journal of Indian Management and Strategy, 11(4), 4-12.

[4] Kumar Raj, Growth and Performance of RRBs in Haryana (1993), Anmol Publications, New Delhi.

[5] Khankhoje Dilip and Sathye Milind, (2008) Efficiency of Rural Banks: The Case of India, International Business Research-CCSE, 1(2).

[6] Lead Bank Scheme, Guidelines, State Bank of India, Chandigarh, (1985).

[7] Patel, M. S. K., \& Japee, G. P. (2019). A Comparative Study of Selected Private and Public Sector Bank with Special Reference to Corporate Social Responsibility in India.Journal of the Gujarat Research Society, 21(16), 3336-3350.

[8] Patel, M. S. K., \& Japee, G. P. To Study the Perception of Banks' Employees towards CSR Activities.

[9] Naidu, L. K. (1988) Bank Finance for Rural Artisans (New Delhi) Ashish Publishing Housing. Narashimham, M. (1991) Report on Reforms of Financial System, Government of India, New Delhi.

[10]Parmar, H. V., \& Japee, G. P. INVESTORS PERSPRECTIVES TOWARDS CO-OPERATIVE BANKS.

[11]Patel K. V. and Shete (1980) RRB performance and prospectus, Prajanan, pp. 1-40.

[12] Patil S. K. (2014) Role of Regional rural banks in rural development of India, Avishkar-Solapur

[13] university journal, 3.

[14] Panandikar, S. G. (1976) Banking in India, Delhi: Orient Longmans. Ramachandran, V. K., and Swaminathan, Madhura (2002) Rural Banking and Landless Labour Households, Institutional Reform and Rural Credit Markets in India, Journal of Agrarian Change, 2, 502-544.

[15]RRB (1986) Financial Express.

[16]Sharma, K. C. (2007) Modern Banking in India, New Delhi: Deep and Deep Publications Pvt. Ltd.

[17]Vyas, M. R. (1991) Financial Performance of Rural Banks, Jaipur: Arihant Publishers.

[18] www.allsubjectjournal.com/archives/download. 